University of Nebraska - Lincoln

DigitalCommons@University of Nebraska - Lincoln

Papers in Biotechnology

Chemical and Biomolecular Engineering

Research and Publications

May 1994

\title{
Effect of Culture Conditions, Donor Age, and Injection Site on In Vitro Development of DNA Microinjected Porcine Zygotes
}

\author{
M A. Hajdu \\ Departments of ${ }^{\star}$ Animal Science, College of Agriculture and Life Sciences, Virginia Agriculture Experiment \\ Station \\ J W. Knight \\ Departments of Animal Science, College of Agriculture and Life SciencesVirginia Agriculture Experiment \\ Station \\ R S. Cansecot \\ Departments of , Dairy Science, College of Agriculture and Life Sciences, \\ R L. Krisher \\ Departments of , Dairy Science, College of Agriculture and Life Sciences, \\ William H. Velander \\ University of Nebraska-Lincoln, wvelander2@unl.edu \\ See next page for additional authors
}

Follow this and additional works at: https://digitalcommons.unl.edu/chemeng_biotechnology

Part of the Biochemical and Biomolecular Engineering Commons

Hajdu, M A.; Knight, J W.; Cansecot, R S.; Krisher, R L.; Velander, William H.; Pearson, R E.; and Gwazdauskas, F C., "Effect of Culture Conditions, Donor Age, and Injection Site on In Vitro Development of DNA Microinjected Porcine Zygotes" (1994). Papers in Biotechnology. 4.

https://digitalcommons.unl.edu/chemeng_biotechnology/4

This Article is brought to you for free and open access by the Chemical and Biomolecular Engineering Research and Publications at DigitalCommons@University of Nebraska - Lincoln. It has been accepted for inclusion in Papers in Biotechnology by an authorized administrator of DigitalCommons@University of Nebraska - Lincoln. 


\section{Authors}

M A. Hajdu, J W. Knight, R S. Cansecot, R L. Krisher, William H. Velander, R E. Pearson, and F C. Gwazdauskas 


\title{
Effect of Culture Conditions, Donor Age, and Injection Site on In Vitro Development of DNA Microinjected Porcine Zygotes ${ }^{1}$
}

\author{
M. A. Hajdu*, J. W. Knight*, R. S. Canseco ${ }^{\dagger}$, R. L. Krisher ${ }^{\dagger}$, W. H. Velander ${ }^{\ddagger}$, \\ R. E. Pearson ${ }^{\dagger}$, and F. C. Gwazdauskas ${ }^{\dagger, 2}$
}

Departments of *Animal Science and †Dairy Science, College of Agriculture and Life Sciences, Virginia Agriculture Experiment Station and $\ddagger$ Department of Chemical Engineering, College of Engineering, Virginia Polytechnic Institute \& State University, Blacksburg 24061

\begin{abstract}
A series of experiments evaluated development of porcine zygotes microinjected with DNA in three culture media and two incubation temperatures, from postpubertal and prepubertal donors, and between zygotes injected with DNA into the pronucleus and the cytoplasm. Zygotes recovered from 36 postpubertal gilts in Exp. 1 were injected and cultured in modified NCSU-23, modified NCSU-37, and $\mathrm{CZB}$ media at $37^{\circ} \mathrm{C}$ or $39^{\circ} \mathrm{C}$ for 7 d. In Exp. 2, zygotes were collected from postpubertal or prepubertal gilts, microinjected with DNA, and cultured in modified NCSU-23. In Exp. 3 superovulated prepubertal gilts had DNA injected into the cytoplasm or pronucleus of zygotes. Mean percentages developing to the expanded or hatched blastocyst stage in modified NCSU-23 (42.9) and modified NCSU-37 (40.1) did not differ, but development was greater than that for
\end{abstract}

zygotes cultured in CZB ( $8.8 ; P<.05)$. Development was greater at $39^{\circ} \mathrm{C}(P<.05)$ than at $37^{\circ} \mathrm{C}(36.5$ vs $24.6 \%$ ). Microinjection of DNA decreased development $(P<.05)$ from that of noninjected controls $(18.1 \mathrm{vs}$ $43.1 \%$ ). Zygotes from postpubertal gilts had a higher percentage (68.0) of expanded and hatched blastocysts than zygotes from prepubertal donors $(29.0 ; P<.05)$. No development difference was found between DNA injection into the pronucleus $(23.1 \%)$ or cytoplasm (17.4\%), but development was less than for control embryos $(64.9 \% ; P<.05)$. DNA microinjected porcine zygotes can be successfully cultured to the expanded blastocyst stage in modified NCSU-23 and modified NCSU-37 media at $39^{\circ} \mathrm{C}$. Microinjection of DNA decreases survival of embryos from prepubertal donors more than it decreases survival of embryos from postpubertal donors.

Key Words: Pigs, Embryos, Microinjection, Culture, Temperature

J. Anim. Sci. 1994. 72:1299-1305

\section{Introduction}

The efficiency of producing transgenic swine is approximately 1\% (Wall et al., 1991). Essential to improving this efficiency is successful embryo development and integration of the injected gene into the endogenous genome. However, microinjected porcine embryos have a decreased rate of survival to blastocyst relative to noninjected controls (Hammer et al., 1986). Additionally, the microinjection of DNA itself was detrimental to embryo development compared with buffer-injected controls (Williams et al., $1992 b$ ).

\footnotetext{
${ }^{1}$ The authors express appreciation to The American Red Cross for partial financial support, R. L. Page, C. G. Russell, B. L. Williams, E. G. Ball, and G. L. Johnson for technical assistance.

${ }^{2}$ Author to whom correspondence should be addressed.

Received September 17, 1993.

Accepted January 5, 1994.
}

A culture system able to support adequate development of porcine embryos microinjected with DNA to the blastocyst stage needs to be refined (Williams et al., 1992b). Among the best development rates for noninjected embryos reported thus far, Krisher et al. (1989) found close to $80 \%$ development to the morula or blastocyst stage for one-cell porcine embryos cultured in mouse oviductal explants. More recently, modified Whitten's medium (French et al., 1993) and modified Krebs-Ringer buffer with the addition of taurine and hypotaurine (NCSU-23; Petters and Reed, 1991) have resulted in greater than $85 \%$ blastocyst development of porcine zygotes.

Embryo development and subsequent transgenic animal production efficiency are affected by the source of embryos and the site of microinjection. Embryos from prepubertal donors had a decreased rate of development in culture (Pinkert et al., 1989) and resulted in fewer pregnancies after transfer to recipients than embryos from postpubertal donors (French et al., 1991; Williams et al., 1992a). Injection 
of DNA into the pronucleus decreased embryo development by approximately $50 \%$ compared with control embryos. Moreover, DNA microinjected into the cytoplasm of porcine embryos resulted in decreased integration frequencies in live-born animals compared with pronuclear injection (Hammer et al., 1986).

Our objectives were to evaluate in vitro development of porcine zygotes microinjected with DNA under different incubation temperatures using three media, to assess the effect of donor age as a source of zygotes upon embryo development, and to evaluate embryo development following microinjection into two different zygotic sites.

\section{Materials and Methods}

\section{Experiment 1}

One-Cell Embryo Recovery. Embryos from crossbred postpubertal gilts $(n=36)$ were used to evaluate three media, two temperatures, and the effect of microinjection on development in vitro in a 3 $\times 2 \times 2$ factorial experiment. Estrous cycles of gilts were synchronized by feeding $17.5 \mathrm{mg}$ of altrenogest (Regu-Mate $7^{\circledR}$, Hoechst-Roussel, Sommerville, NJ) for 5 to $9 \mathrm{~d}$ between $\mathrm{d} 12$ and 16 of the estrous cycle (Williams et al., 1992a). Fifteen hundred international units of PMSG (Diosynth, Chicago, IL) were administered i.m. $24 \mathrm{~h}$ after the last altrenogest feeding. Five hundred international units of hCG (Lyphomed, Rosemont, IL) were injected i.m. $65 \mathrm{~h}$ after PMSG injection. Gilts were bred by $\mathrm{AI} 32$ and 40 $h$ after hCG injection, and surgery was performed 15 to $20 \mathrm{~h}$ later. Anesthesia was induced with $1.5 \mathrm{~g}$ of thiopental sodium (Pentothal ${ }^{\oplus}$, Abbott Laboratories, Chicago, IL) and maintained with halothane and nitrous oxide. Oviducts were exteriorized by midventral laparotomy. A retrograde oviductal flush was performed from the utero-tubal junction to the infundibulum with $20 \mathrm{~mL}$ of Beltsville Embryo Culture Medium (V. G. Pursel, personal communication), a HEPES-buffered medium for handling embryos in air (Williams et al., 1992b).

Embryo Micromanipulation. Embryos from each donor were centrifuged at $15,000 \times g$ for $12 \mathrm{~min}$ to enable visualization of the pronuclei (Wall et al., 1985). All embryos were placed in the injection chamber and evaluated at $200 \times$ magnification. Every other one-cell embryo with visible pronuclei was injected; the other was used as a control. Ova with no visible pronuclei were classified as unfertilized. Two to four picoliters of the DNA construct (200 copies $/ \mathrm{pL}$, $1.5 \mu \mathrm{g} / \mathrm{mL})$ in buffer $(10 \mathrm{~m} M$ Tris-HCl, $.25 \mathrm{mM}$ EDTA) was injected into one of the pronuclei. The fusion gene was a $5.5-\mathrm{kb} \mathrm{cDNA}$ construct of human Protein $\mathrm{C}$ ( $\mathrm{PC}$ ) placed between fragments of the Whey Acidic Protein promoter (PC3). Unlike the PC1 construct used by Velander et al. (1992), the PC3 construct had all introns and exons removed from WAP and only included fragments $2.6 \mathrm{~kb}$ upstream of the start codon and 1.3 to $1.6 \mathrm{~kb}$ downstream of the stop codon. Embryos from each donor were randomized across treatments. Embryos within each treatment were pooled and cultured together.

Embryo Culture. The three culture media evaluated were NCSU-23 (Petters and Reed, 1991), CZB medium (Chatot et al., 1989), and NCSU-37 (Petters and Wells, 1993). Medium NCSU-23 was modified by excluding hypotaurine. Medium NCSU-37 contains sorbitol instead of taurine and hypotaurine but was modified by substituting mannitol for sorbitol. Glucose and glutamine were included in CZB medium. All media were prepared in $100-\mathrm{mL}$ volumes and stored at $-87^{\circ} \mathrm{C}$ in $10-\mathrm{mL}$ aliquots. The day before embryo culture, aliquots were thawed and filtered $(.2 \mu \mathrm{m})$ into dishes. A culture dish was prepared with six $20-\mu \mathrm{L}$ microdrops overlaid with silicone oil and labeled according to treatment and media. All dishes were allowed to equilibrate overnight in a humid atmosphere of $5 \% \mathrm{CO}_{2}$. All embryos in each treatment were randomized equally to media groups. Each group of embryos was subjected to three washes in one of the three culture media and placed in a corresponding microdrop. This procedure was repeated for the remaining treatment groups. Embryos were incubated at either $37^{\circ} \mathrm{C}$ or $39^{\circ} \mathrm{C}$. Embryos were considered viable if they were expanded or hatched blastocysts after $7 \mathrm{~d}$.

\section{Experiment 2}

The development rate of microinjected embryos from pre- and postpubertal donor gilts was evaluated in a $2 \times 2$ factorial experiment. Prepubertal gilts ( $\mathrm{n}=$ 14) 157 to $189 \mathrm{~d}$ of age were synchronized with an i.m. injection of 1,500 IU of PMSG and induced to ovulate with $500 \mathrm{IU}$ of hCG $72 \mathrm{~h}$ later (Dziuk and Baker, 1962; Guthrie, 1977). Gilts were bred by AI 24 and 32 $\mathrm{h}$ after hCG. Postpubertal donors $(\mathbf{n}=15)$ were synchronized as described in Exp. 1. Both donor types were flushed on each day of surgery. Postpubertal and prepubertal gilts were alternated in the surgical schedule. Embryos were pooled according to donor type and treatment and handled as previously described. Development was assessed after culture in modified NCSU-23 at $39^{\circ} \mathrm{C}$ for $7 \mathrm{~d}$.

\section{Experiment 3}

Embryos from prepubertal donors $(n=22) 186$ to $201 \mathrm{~d}$ of age were used to study the effect of microinjection of DNA into the pronucleus and cytoplasm on development. After collection as described in Exp. 2, embryos from each donor were placed in an injection chamber. One-third of the embryos with visible pronuclei were injected cytoplasmically, one-third were held as controls, and one-third 
Table 1. Superovulatory responses of postpubertal and prepubertal gilts

\begin{tabular}{|c|c|c|c|c|c|c|c|}
\hline Item & $\begin{array}{l}\text { No. of } \\
\text { gilts }\end{array}$ & Ovulations/gilt & $\begin{array}{c}\% \\
\text { Recovery }\end{array}$ & Embryos/gilt & $\begin{array}{c}\% \\
\text { Fertilized }^{\mathrm{a}}\end{array}$ & $\begin{array}{c}\text { One-Cell } \\
\text { embryos/gilt }\end{array}$ & $\begin{array}{l}\% \text { UFO } \\
\text { cleaved }^{b}\end{array}$ \\
\hline Exp. 1 & 34 & $25.4 \pm 1.6^{\mathrm{c}}$ & 86.4 & $22.0 \pm 2.2$ & 57.6 & $12.6 \pm 1.5$ & - \\
\hline \multicolumn{8}{|l|}{ Exp. 2} \\
\hline Postpubertal & 15 & $22.1 \pm 2.7$ & 76.8 & $17.0 \pm 2.2$ & 61.9 & $10.5 \pm 2.1$ & 77.5 \\
\hline Prepubertal & 14 & $23.8 \pm 3.7$ & 58.7 & $14.0 \pm 3.2$ & 44.3 & $6.2 \pm 3.0$ & 78.0 \\
\hline \multicolumn{8}{|l|}{ Exp. 3} \\
\hline Prepubertal & 22 & $27.4 \pm 2.0$ & 82.3 & $22.5 \pm 2.1$ & 70.3 & $15.8 \pm 1.4$ & 82.4 \\
\hline
\end{tabular}

aPercentage of oocytes with two visible pronuclei following centrifugation at the time of microinjection.

bUnfertilized ova.

$\mathrm{c}_{\text {Mean }} \pm \mathrm{SE}$.

had DNA microinjected into the pronucleus. Polylysine (DP 17, Sigma Chemical, St. Louis, MO), a polypeptide of 17 lysine residues per chain, was included in the injection buffer for cytoplasmic injections (DNA concentration $1.5 \mu \mathrm{g} / \mathrm{mL}$ ). Polylysine was included in the cytoplasmic injection buffer to associate with and stabilize the DNA construct (Laemmli, 1975) to prevent its rapid degradation, thereby increasing the chances of its migration and integration into the endogenous nuclear material. Embryos were cultured in modified NCSU-23 at $39^{\circ} \mathrm{C}$ for $7 \mathrm{~d}$.

\section{Statistical Analysis}

Embryo development was analyzed using GLM procedures in SAS (1985). Development at d 7 was coded 0 for fragmented embryos, 1 for one cell, 2 for two cells, 3 for three cells, 4 for four cells, 5 for six cells, 6 for eight cells, 7 for compact morula, 8 for blastocyst, 9 for expanded blastocyst, and 10 for hatched blastocyst. The model for Exp. 1 included media, treatment, temperature, and their interactions. The model for Exp. 2 included donor source, treatment, and their interactions. The model for Exp. 3 included treatment. The number of embryos per microdrop was included as a covariate in all three models. Differences in least squares means were evaluated using nonorthogonal contrasts and tested using Bonferroni improved $F$ statistic. Least squares means for significant interactions were evaluated using Tukey's pairwise comparisons.

\section{Results}

Responses to superovulation and synchronization schedules for the collection of one-cell embryos are summarized in Table 1. Data were unavailable for two gilts from which embryos were recovered and included in the culture studies of Exp. 1. No significant differences were observed between the ovulatory response of gilts or between prepubertal and postpubertal gilts. The number of one-cell embryos appropriate for microinjection was approximately half the number of ovulations. Embryos that were classified as unfertilized during the injection process and then incubated later demonstrated a high incidence of cleavage (Exp. 2 and 3 ). The comparable percentages of unfertilized ova cleaving for both postpubertal and prepubertal gilts in Exp. 2 indicated that the timing of surgery did not favor either group.

\section{Experiment 1}

Percentages of DNA microinjected and noninjected zygotes that developed to the expanded or hatched

Table 2. Effect of media and the interaction of temperature $\times$ microinjection treatment on percentage of porcine zygotes developing to expanded or hatched blastocyst after 7 days in culture

\begin{tabular}{|c|c|c|c|c|c|}
\hline \multirow[b]{2}{*}{ Treatment } & \multicolumn{3}{|c|}{ Medium } & \multirow{2}{*}{\multicolumn{2}{|c|}{ Treatment avg }} \\
\hline & Modified NCSU-23 & Modified NCSU-37 & $\mathrm{CZB}$ & & \\
\hline \multicolumn{6}{|l|}{$37^{\circ} \mathrm{C}$} \\
\hline Injected & $23.1 \pm 6.6$ & $23.1 \pm 6.6$ & $1.4 \pm 6.6$ & $15.9 \pm 3.9^{\mathrm{a}}$ & (111) \\
\hline Noninjected & $43.4 \pm 7.0$ & $44.6 \pm 6.8$ & $12.0 \pm 7.3$ & $33.4 \pm 4.1^{b}$ & $(100)$ \\
\hline \multicolumn{6}{|l|}{$39^{\circ} \mathrm{C}$} \\
\hline Injected & $29.7 \pm 5.8$ & $22.1 \pm 6.4$ & $8.8 \pm 6.5$ & $20.2 \pm 3.7^{\mathrm{ab}}$ & $(128)$ \\
\hline Noninjected & $75.2 \pm 6.2$ & $70.3 \pm 6.5$ & $12.6 \pm 6.6$ & $52.8 \pm 3.8^{\mathrm{c}}$ & $(119)$ \\
\hline Medium avg & $42.9 \pm 3.2^{\mathrm{a}}(162)^{\mathrm{d}}$ & $40.1 \pm 3.3^{\mathrm{a}}(152)$ & $8.8 \pm 3.4^{b}(144)$ & - & \\
\hline
\end{tabular}

$a, b, c$ Least squares means within a row or column lacking a common superscript differ $(P<.05)$.

$\mathrm{d}_{\text {Number }}$ of samples given in parentheses. 
Table 3. Interaction of media by microinjection treatment on percentage of porcine zygotes developing to expanded or hatched blastocysts after 7 days in culture

\begin{tabular}{lccr}
\hline & \multicolumn{3}{c}{ Medium } \\
\cline { 2 - 4 } Treatment & \multicolumn{1}{c}{ Modified NCSU-23 } & Modified NCSU-37 & \multicolumn{1}{c}{ CZB } \\
\hline Injected & $26.4^{\mathrm{a}} \pm 4.4(85)^{\mathrm{d}}$ & $22.6^{\mathrm{ab}} \pm 4.6(78)$ & $5.2^{\mathrm{b}} \pm 4.6(76)$ \\
Noninjected & $59.3^{\mathrm{c}} \pm 4.6(77)$ & $57.5^{\mathrm{c}} \pm 4.7(74)$ & $12.4^{\mathrm{ab}} \pm 4.9(68)$ \\
\hline \multicolumn{2}{c}{ a,b,c Least squares means lacking a common superscript differ $(P<.05)}$. & \\
d Number of samples given in parentheses. & &
\end{tabular}

blastocyst stage in modified NCSU-23 or modified NCSU-37 were both greater than the development in CZB medium $(P<.05$; Table 2$)$ but were not different from each other $(P>.05)$. Zygotes cultured at $39^{\circ} \mathrm{C}$ across all three media had a greater percentage of embryo development $(36.5 \pm 2.7 ; \mathrm{n}=247$ vs $24.6 \pm$ $2.9 \% ; \mathrm{n}=211)$ than zygotes cultured at $37^{\circ} \mathrm{C}(P<$ $.05)$. Microinjection decreased development (18.1 \pm $2.6 ; \mathrm{n}=239$ vs $43.1 \pm 2.8 \%, \mathrm{n}=219$ ) from that of $\mathrm{no}$ injection $(P<.05)$. The significant interaction of media by injection treatment (Table 3 ) demonstrated that control embryos cultured in modified NCSU-23 or modified NCSU-37 developed at a higher percentage than all other groups $(P<.05)$ but did not develop differently from each other $(P>.05)$. The significant interaction $(P<.05)$ of temperature by treatment (Table 2) demonstrated that noninjected embryos incubated at $39^{\circ} \mathrm{C}$ had the greatest development to expanded or hatched blastocyst. In addition, the number of embryos per $20-\mu \mathrm{L}$ drop was included as a covariate and yielded a regression coefficient of .02 .

\section{Experiment 2}

DNA microinjected and noninjected zygotes from postpubertal donors had a greater percentage of development to the expanded or hatched blastocyst stage than zygotes from prepubertal gilts $(P<.05)$ after a 7 -d culture in modified NCSU-23 at $39^{\circ} \mathrm{C}$ (Table 4). Microinjection decreased embryo development across both donor sources compared with no injection $(P<.05$; Table 5$)$.

Table 4. Effect of donor source on percentage of porcine zygotes developing to the expanded or hatched blastocyst stage after 7 days of culture in NCSU-23

\begin{tabular}{lccc}
\hline \hline Donor & $\mathrm{n}$ & Percentage & Mean cell no. \\
\hline Postpubertal & 158 & $68.0^{\mathrm{c}} \pm 3.4$ & $6.4 \pm .3$ \\
Prepubertal & 87 & $29.0^{\mathrm{d}} \pm 4.6$ & $3.0 \pm .4$ \\
\hline
\end{tabular}

${ }^{a}$ Combined injected and noninjected embryo development.

bWhere $0=$ fragmented; $1=$ one cell; $2=$ two cells; $3=$ three cells; $4=$ four cells; $5=$ six cells; $6=$ eight cells; $7=$ compact morula; $8=$ blastocyst; $9=$ expanded blastocyst; $10=$ hatched blastocyst.

c,d Least squares means within a column lacking a common superscript differ $(P<.05)$.

\section{Experiment 3}

The mean percentages of embryo development for pronuclear DNA injection and cytoplasmic DNA injection were not different from each other $(P>.05)$ but were both less than the embryo development for no injection $(P<.05$, Table 6$)$. The number of embryos per 20- $\mu \mathrm{L}$ drop included as a covariate resulted in a regression coefficient of .008 .

\section{Discussion}

There was a consistent response to synchronization and superovulation for the collection of one-cell porcine embryos. Williams et al. (1992a) observed no difference in ovulation rates or zygotes per animal between prepubertal gilts and postpubertal gilts synchronized with altrenogest, as was seen in this study. The prepubertal gilts used in Exp. 3 were approximately $30 \mathrm{~d}$ older than the prepubertal gilts used in Exp. 2, which may help to explain the improved embryo recovery seen in this study. Although their work was conducted on postpubertal animals, Archibong et al. (1992) noted an effect of one estrous cycle, reporting an increase in ovulation rates from first to second estrus in gilts. The high percentage of ova classified as unfertilized that cleaved could indicate that surgical embryo collection was too early. Embryo stage variability also may have been increased due to the administration of hCG to induce

Table 5. Effect of DNA microinjection on percentage of porcine zygotes developing to the expanded or hatched blastocyst stage after 7 days of culture in NCSU-23a

\begin{tabular}{lccc}
\hline \hline Treatment & $\mathrm{n}$ & Percentage & Mean cell no. \\
\hline Injected & 127 & $29.3^{\mathrm{c}} \pm 4.0$ & $3.6 \pm .4$ \\
Noninjected & 118 & $67.6^{\mathrm{d}} \pm 4.1$ & $6.9 \pm .4$ \\
\hline
\end{tabular}

${ }^{a}$ Combined postpubertal and prepubertal embryo development.

bWhere $0=$ fragmented; $1=$ one cell; $2=$ two cells; $3=$ three cells; $4=$ four cells; $5=$ six cells; $6=$ eight cells; $7=$ compact morula; $8=$ blastocyst; 9 = expanded blastocyst; $10=$ hatched blastocyst.

$c$,d Least squares means within a column lacking a common superscript differ $(P<.05)$. 
Table 6. Effect of site of DNA microinjection on percentage of prepubertal porcine zygotes developing

to the expanded or hatched blastocyst stage after 7 days of culture in NCSU-23

\begin{tabular}{lccc}
\hline \hline Treatment & $\mathrm{n}$ & Percentage & Mean cell no. \\
\hline Pronuclear injected & 114 & $23.1^{\mathrm{b}} \pm 4.0$ & $3.5 \pm .4$ \\
Cytoplasmic injected & 122 & $17.4^{\mathrm{b}} \pm 4.0$ & $3.3 \pm .4$ \\
Noninjected & 107 & $64.9^{\mathrm{c}} \pm 4.2$ & $6.6 \pm .4$ \\
\hline
\end{tabular}

aWhere $0=$ fragmented; $1=$ one cell; $2=$ two cells; $3=$ three cells; $4=$ four cells; $5=$ six cells; $6=$ eight cells; $7=$ compact morula; $8=$ blastocyst; 9 = expanded blastocyst; $10=$ hatched blastocyst.

$\mathrm{b}, \mathrm{c}$ Least squares means within a column lacking a common superscript differ $(P<.05)$.

ovulation, which was reported to increase the duration of ovulation above that of natural cyclicity (Soede et al., 1992).

From the results of Exp. 1, it was demonstrated that both modified NCSU-23 and modified NCSU-37 were capable of supporting development of DNA microinjected porcine zygotes to the expanded or hatched blastocyst stage in vitro. Our study supports the superiority of NCSU-23 reported for noninjected embryos by Petters and Reed (1991), Illera et al. (1992), and Torres and Rath (1992). Medium NCSU23 contains taurine, an amino acid found in abundance in oviductal fluid that improved development of porcine embryos when included alone or in combination with hypotaurine in culture media (Petters and Reed, 1991). However, Petters and Wells (1993) observed no difference between media NCSU-23 and NCSU-37 in their ability to support embryo development. Media NCSU-23 and NCSU-37 both contain glucose and glutamine, which were shown to be important sources of energy substrate for porcine embryos by Petters et al. (1990). However, NCSU-37 lacks taurine, which may indicate that another shared component of these two media was responsible for the improved development above that of other culture media. It also may indicate that the inclusion of sorbitol in NCSU-37 provided a nutritive benefit comparable to taurine. However, mannitol was substituted for sorbitol in our experiment and comparable development rates were observed. The development rates observed for one-cell porcine embryos cultured in CZB supplemented with glucose do not support the $51 \%$ development to blastocysts reported by Misener et al. (1991). Although media composition and culture conditions seem to be similar for both studies, the difference in development may be due to animal manipulation and superovulation compared to observation of natural estrus for the collection of one-cell embryos.

The direct evaluation of the effect of temperature in Exp. 1 demonstrated increased development at $39^{\circ} \mathrm{C}$ compared with $37^{\circ} \mathrm{C}$, which had not been reported previously. Observations also indicated an increased rate of development at $39^{\circ} \mathrm{C}$. Successful culture of porcine embryos to the blastocyst stage has been reported at $37^{\circ} \mathrm{C}$ (Krisher et al., 1989; Petters and Reed, 1991) and $38^{\circ} \mathrm{C}$ (Illera et al., 1992), with other studies conducted at $39^{\circ} \mathrm{C}$ (Beckmann and Day, 1991; French et al., 1993). However, no direct comparison of incubation temperature was found in the literature for porcine embryo culture. Porcine body temperature measured rectally is $39.2^{\circ} \mathrm{C}$ (Andersson, 1970). The higher temperature of incubation used in this study may closer approximate core temperature experienced by developing embryos.

The comparison of postpubertal and prepubertal donor embryos in Exp. 2 demonstrated a decreased ability of microinjected and noninjected embryos collected from prepubertal gilts to develop in vitro, which also was reported by Pinkert et al. (1989) for noninjected embryos. In addition, French et al. (1991) and Williams et al. (1992a) reported that embryos from prepubertal donors resulted in fewer pregnancies after transfer to recipients compared with transfers with embryos from postpubertal donors. Although prepubertal gilts are able to respond to an exogenous superovulatory stimulus, the decreased viability of prepubertal embryos may be due to immaturity of the ovulated ova or an inadequate hormonal environment (Christenson et al., 1985). Moreover, prepubertal gilts in our study were not given altrenogest. Additionally, Wiesak et al. (1990) reported a decrease in follicle numbers and fluid volume and an increased variability in follicular diameter and oocyte maturation in prepubertal gilts compared to postpubertal gilts.

No direct assessment of the effect of culture volume on porcine embryo development has yet heen reported. In the mouse and cow (Paria and Dey, 1990; Canseco et al., 1992; Dessy et al., 1993) high culture volume and single embryo culture are associated with decreased development. However, porcine embryos have been cultured successfully in as much as $3 \mathrm{~mL}$ of medium (Blum-Reckow and Holtz, 1991). In addition, Williams et al. (1992b) did not detect a difference in cleavage index between the addition of 3 or 13 zygotes to organ culture systems. We report a significant beneficial effect on the developmental percentage of the inclusion of as many as 50 embryos in one $20-\mu \mathrm{L}$ drop. A range of 25 to 35 embryos was included in each experiment. For each additional embryo the percentage to reach expanded blastocyst increased between .8 to 2 . Studies in the mouse and cow indicate that cooperative interaction occurs between embryos cultured together, possibly through the secretion of growth factors. Paria and Dey (1990) reported that the addition of growth factors (epidermal growth factor and transforming growth factor $\alpha$ ) to the culture drop improved development of two-cell mouse embryos. The presence of receptors for these growth factors were reported to be found on the embryonic cell 
surface. Although mouse embryos were not tested for their secretion of growth factors, the results imply such a cooperative interaction, although it remains to be elucidated. A similar phenomenon may also occur among porcine embryos, although no direct evidence exists. Early porcine embryos may benefit from the cooperative interaction of growth factors present in small culture volumes.

The percentage of DNA microinjected embryos developing to the expanded blastocyst stage observed in these experiments is consistent with the $50 \%$ decrease in survival from control embryo development reported by Hammer et al. (1986) and French et al. (1993). A decrease in development comparable to DNA injection into the pronucleus was also observed for DNA injection into the cytoplasm. DNA injected into the cytoplasm of one-cell embryos resulted in decreased integration frequencies in murine (Brinster et al., 1985), porcine (Hammer et al., 1986), and bovine models (Gagne et al., 1993) compared with pronuclear DNA injection. If embryos injected with DNA cytoplasmically had shown an increased rate of survival from that of DNA injection into the pronucleus, the improved viability may have compensated for lower integration frequencies. However, improved survival with injection of DNA into the cytoplasm was not observed. Survival may have been affected by physical trauma, the inclusion of polylysine in the buffer, or the negative effect of DNA reported by Williams et al. (1992b).

\section{Implications}

Modified NCSU-23 and NCSU-37 media are effective systems that can be used to culture DNA microinjected porcine zygotes to the expanded and hatched blastocyst stages of development at $39^{\circ} \mathrm{C}$. Survival of embryos collected from both postpubertal and prepubertal gilts is decreased following microinjection of DNA; however, postpubertal embryos exhibited a higher rate of development in vitro. Injection of DNA into the cytoplasm does not improve the rate of survival of zygotes to blastocysts compared with injection of DNA into the pronucleus.

\section{Literature Cited}

Andersson, B. E. 1970. Temperature regulation and environmental physiology. In: M. J. Swenson (Ed.) Dukes' Physiology of Domestic Animals. p 1121. Cornell University Press, Ithaca, NY.

Archibong, A. E., R. R. Maurer, D. C. England, and F. Stormshak. 1992. Influence of sexual maturity of donor on in vivo survival of transferred porcine embryos. Biol. Reprod. 47:1026.

Beckmann, L. S., and B. N. Day. 1991. Culture of the one- and twocell porcine embryo: Effects of varied osmolarity in Whitten's and Kreb's Ringer Bicarbonate media. Theriogenology 35:184 (Abstr.).
Blum-Reckow, B., and W. Holtz. 1991. Transfer of porcine embryos after 3 days of in vitro culture. J. Anim. Sci. 69:3335.

Brinster, R. L., H. Y. Chen, M. E. Trumbauer, M. K. Yagle, and R. D. Palmiter. 1985. Factors affecting the efficiency of introducing foreign DNA into mice by microinjecting eggs. Proc. Natl. Acad. Sci. USA 82:4438.

Canseco, R. S., A.E.T. Sparks, R. E. Pearson, and F. C. Gwazdauskas. 1992. Embryo density and medium volume effects on early murine embryo development. J. Assist. Reprod. Genet. 9:454.

Chatot, C. L., C. A. Ziomek, B. D. Bavister, J. L. Lewis, and I. Torres. 1989. An improved culture medium supports development of random-bred 1-cell mouse embryos in vitro. J. Reprod. Fertil. 86:679.

Christenson, R. K., J. J. Ford, and D. A. Redmer. 1985. Maturation of ovarian follicles in the prepubertal gilt. J. Reprod. Fertil. Suppl. 33:21.

Dessy, F., F. Ferry, P. Mermillod, and A. Massip. 1993. Bovine embryos cultured in serum-free conditioned-medium need cooperation to reach the blastocyst stage. Biol. Reprod. 48:172 (Abstr.).

Dziuk, P. J., and R. D. Baker. 1962. Induction and control of ovulation in swine. J. Anim. Sci. 21:697.

French, A. J., P. Zviedrans, R. J. Ashman, A. Cecil, and R. F. Seamark. 1993. Viability of porcine embryos cultured in simple media. Theriogenology 39:219 (Abstr.).

French, A. J., P. Zviedrans, R. J. Ashman, P. A. Heap, and R. F. Seamark. 1991. Comparison of prepubertal and postpubertal young sows as a source of one-cell embryos for microinjection. Theriogenology 35:202 (Abstr.).

Gagne, M., F. Pothier, and M. A. Sirard. 1993. Foreign gene expression in activated oocytes and bovine embryos following pAGSlacZ plasmid microinjection. Theriogenology 39:223 (Abstr.).

Guthrie, H. D. 1977. Induction of ovulation and fertility in prepubertal gilts. J. Anim. Sci. 45:1360.

Hammer, R. E., V. G. Pursel, C. E. Rexroad, Jr., R. J. Wall, D. J. Bolt, R. D. Palmiter, and R. L. Brinster. 1986. Genetic engineering of mammalian embryos. J. Anim. Sci. 63:269.

Illera, M. J., P. Lorenzo, J. C. Illera, G. Silvan, A. Portela, and R. M. Petters. 1992. A simple medium supports in vitro development of one-cell embryos from miniature pigs to the blastocyst stage. Theriogenology 37:225 (Abstr.).

Krisher, R. L., R. M. Petters, B. H. Johnson, B. D. Bavister, and A. E. Archibong. 1989. Development of porcine embryos from the one-cell stage to blastocyst in mouse oviducts maintained in organ culture. J. Exp. Zool. 249:235.

Laemmli, U. K. 1975. Characterization of DNA condensates induced by poly(ethylene oxide) and polylysine. Proc. Natl. Acad. Sci. USA 72:4288.

Misener, M., J. W. Pollard, and K. Metzger. 1991. In vitro culture of porcine embryos in CZB medium. Theriogenology 35:244 (Abstr.).

Paria, B. C., and S. K. Dey. 1990. Preimplantation embryo development in vitro: Cooperative interactions among embryos and role of growth factors. Proc. Natl. Acad. Sci. USA 87:4756.

Petters, R. M., B. H. Johnson, M. L. Reed, and A. E. Archibong. 1990. Glucose, glutamine and inorganic phosphate in early development of the pig embryo in vitro. J. Reprod. Fertil. 89: 269.

Petters, R. M., and M. L. Reed. 1991. Addition of taurine or hypotaurine to culture medium improves development of one- and twocell pig embryos in vitro. Theriogenology 35:253 (Abstr.).

Petters, R. M., and K. D. Wells. 1993. Culture of pig embryos. J. Reprod. Fertil. Suppl. 48:61.

Pinkert, C. A., D. L. Kooyman, A. Baumgartner, and D. H. Keisler. 1989. In-vitro development of zygotes from superovulated prepubertal and mature gilts. J. Reprod. Fertil. 87:63.

Pope, W. F., M. H. Wilde, and S. Xie. 1988. Effect of electrocautery of nonovulated day 1 follicles on subsequent morphological variation among day 11 porcine embryos. Biol. Reprod. 39:882.

SAS. 1985. SAS User's Guide:Statistics (Version 5 Ed.). SAS Inst. Inc., Cary, NC. 
Soede, N. M., J.P.T.M. Noordhuizen, and B. Kemp. 1992. The duration of ovulation in pigs, studied by transrectal ultrasonography, is not related to early embryonic diversity. Theriogenology 38:653.

Torres, C.R.L., and D. Rath. 1992. In vitro culture of porcine embryos to the blastocyst stage after in vivo or in vitro fertilization. Theriogenology 37:283 (Abstr.).

Velander, W. H., J. L. Johnson, R. L. Page, C. G. Russell, A. Subramanian, T. D. Wilkins, F. C. Gwazdauskas, C. Pittius, and W. N. Drohan. 1992. High-level expression of a heterologous protein in the milk of transgenic swine using the cDNA encoding human protein C. Proc. Natl. Acad. Sci. USA 89: 12003.

Wall, R. J., V. G. Pursel, R. E. Hammer, and R. L. Brinster. 1985. Development of porcine ova that were centrifuged to permit visualization of pronuclei and nuclei. Biol. Reprod. 32:645.

Wall, R. J., V. G. Pursel, A. Shamay, R. A. McKnight, C. W. Pittius, and L. Hennighausen. 1991. High-level synthesis of a heterolo- gous milk protein in the mammary glands of transgenic swine. Proc. Natl. Acad. Sci. USA 88:1696.

Wiesak, T., M. G. Hunter, and G. R. Foxcroft. 1990. Differences in follicular morphology, steroidogenesis and oocyte maturation in naturally cyclic and PMSG/hCG-treated prepubertal gilts. J. Reprod. Fertil. 89:633.

Williams, B. L., A.E.T. Sparks, R. S. Canseco, J. W. Knight, J. L. Johnson, W. H. Velander, R. L. Page, W. N. Drohan, E. T. Kornegay, R. E. Pearson, T. D. Wilkins, and F. C. Gwazdauskas. 1992a. Evaluation of systems for collection of porcine zygotes for DNA microinjection and transfer. Theriogenology 38:501.

Williams, B. L., A.E.T. Sparks, R. S. Canseco, J. W. Knight, J. L. Johnson, W. H. Velander, R. L. Page, W. N. Drohan, J. M. Young, R. E. Pearson, T. D. Wilkins, and F. C. Gwazdauskas. $1992 \mathrm{~b}$. In vitro development of zygotes from prepubertal gilts after microinjection of DNA. J. Anim. Sci. 70:2207. 